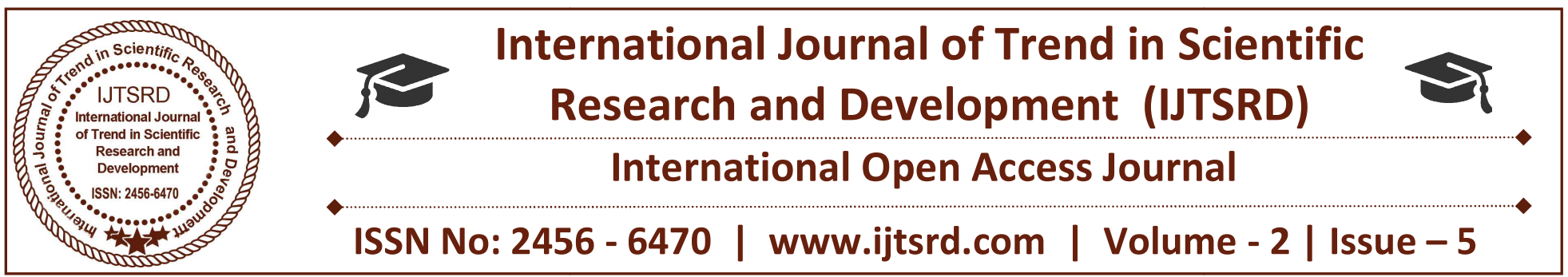

\title{
Risk Factors of Increasing Divorce Petitions in Courts
}

\author{
Anjali Rani \\ Ph.D in Social Work, Medical Social Worker \\ Government Medical College and Hospital, Sector 32B, Chandigarh, India
}

\begin{abstract}
Background: The number of divorce cases is increasing rapidly every year in our country. It has become the serious problem not only in India but in all over the world. Matrimonial disputes consist of various issues that became the major causes of involvement in divorce cases. These issues may be interference of parental families, lack of patience, consumption of alcohol/drugs, incompatibility issues, economic crisis and mental torture. Besides this, concealment of facts, sexual incompatibilities, nonacceptance of girl child, unrealistic expectations etc. further lead to marital discords among the couples. These concentrated marital conflict issues affect the social, psychological and economical wellbeing of women who are involved in divorce cases.
\end{abstract}

Methodology: The sample is drawn of 300 women in four districts of Punjab who are involved in divorce cases. Structured Interview Schedule is designed to collect data.

Results: Various issues are found as the major causes of filing divorce cases in the courts in which lack of patience is the most significant factor that is 82.66 per cent of total cases.

Keywords: Marriage; Incompatibility; Matrimonial Disputes; Conflict; Social; Psychological; Economical; Violence; Relationship

\section{INTRODUCTION}

Matrimonial disputes have become the major social problem in today's times. Marriage is a social institution that is considered as a sacred relationship between man and woman. It is a lifelong commitment of personal and social values for the welfare of family and society. But with the passage of time and advent of civilization, two concepts of individual right and individual liberty of choice have put a question mark on the marriage as a social institution. The individual liberty and economic independence especially of women, the assertions of personal rights have overridded the duties towards the family and society which has gone a long way in destabilizing indissoluble sacramental bond (Gopal, 2014).

Marital disputes are rising not only due to a single factor but generates from multiple factors. Example the habits of drug consumption further give rise to poor economical condition and domestic violence. Female spouses have to face physical and mental torture, humiliations and harassments. So, matrimonial disputes are rising by various reasons that further lead to certain other issues.

Objectives of the study:

To explore the major factors that becomes the cause of involvement in divorce cases.

Examine the proportion of these factors that further lead to file divorce petitions in the court.

To recommend various suggestions on which parents and spouses should focus to avoid future marital disharmonies.

\section{Research Methodology:}

The methodology adopted for the present study is primarily descriptive in nature. In order to draw a representative sample of 300 respondents, 75 women are randomly chosen for interview from four districts $(75 X 4=300)$ namely Patiala, Sangrur, Barnala and Fatehgarh Sahib who are either petitioners or respondents of divorce cases filed in various courts in 
such districts. The primary tool of data collection is Structured Interview Schedule. Apart from this, observation and group discussion is also be used when necessary.

\section{Survey findings:}

Table 1: Causes of Matrimonial Disputes

\begin{tabular}{|c|c|c|c|}
\hline \multirow[b]{2}{*}{$\begin{array}{l}\text { Sr. } \\
\text { No. }\end{array}$} & \multirow[b]{2}{*}{$\begin{array}{c}\text { Causes of Matrimonial } \\
\text { Disputes }\end{array}$} & \multicolumn{2}{|c|}{ Responses } \\
\hline & & $\mathbf{N}$ & $\begin{array}{l}\text { Percent } \\
\text { of cases } \\
\mathbf{N}=300\end{array}$ \\
\hline 1 & Lack of Patience & 248 & $82.66 \%$ \\
\hline 2 & $\begin{array}{l}\text { Interference of Parental } \\
\text { Family (of either spouse) }\end{array}$ & 192 & $64.0 \%$ \\
\hline 3 & Incompatibility Issues & 187 & $62.33 \%$ \\
\hline 4 & Economic Reasons & 143 & $47.66 \%$ \\
\hline 5 & Drug Consumption & 143 & $47.66 \%$ \\
\hline 6 & $\begin{array}{c}\text { Internet/Mobile Phone } \\
\text { Addiction }\end{array}$ & 124 & $41.33 \%$ \\
\hline 7 & Mental Torture by in-laws & 121 & $40.33 \%$ \\
\hline 8 & $\begin{array}{c}\text { Domestic Violence \& } \\
\text { Dowry Harassment }\end{array}$ & 91 & $30.33 \%$ \\
\hline 9 & Suspicion in marriage & 80 & $26.66 \%$ \\
\hline 10 & Unfaithfulness in marriage & 66 & $22.0 \%$ \\
\hline
\end{tabular}

The total number of research cases with regard to the causes of matrimonial disputes is 300 . The most common cause behind filing of divorce cases is lack of patience among spouses which is 82.66 per cent of total cases. The second highest proportion is showing the interference of parental families that became the cause of involvement of spouses in divorce cases. The survey further demonstrates the equal proportion (47.66 per cent) of economic reasons and drug consumption by male spouses which raised marital disharmonies and forced women to breakdown of marriage.

Causes of Matrimonial Disputes: In modern society, the nature of disputes among spouses is changing. Earlier the issues relating to marital conflicts were found as domestic violence, dowry demands, in-laws dominance, humiliations \& harassments etc. Women were considered as dependent person who were expected to bear dominance and violence of her inlaws. But in recent times, the nature of disputes in Indian marriages has changed in the form of interference by wives' parental family, excessive use of mobile phones, unfaithfulness in marriage, concealment of facts, incompatibility issues, serious disease (infirmity), materialism, economic insecurities, ambitions and self interests etc. Various causes of marital disputes are listed as below:

1. Lack of Patience: Excessive anger is one of the major reasons of marital and family discords. It is a serious threat to family psychological and spiritual health. Marital relationships often improve when spouses politely request for insensitivities and hurts. When the spouse tries to understand and to forgive, anger diminishes, trust increases and emotional closeness also comes to exist. It further leads to the purification of marital memory that results in a diminished likelihood of overreacting in anger towards one's spouse in the future (Fibzgibbons, 2017). It is important to note that the data is depicted not only of female spouses but it is included the percentage of lack of patience by male spouses also. Patience is very necessary to build up harmonious relationship. Marital relationship really needs temperament for both spouses. But spouses don't have ounce of patience to their marriage intact.

2. Interference of parental family: Interference of parents has become the major reason of couples' disputes. It is found not only by in-laws side but by wife's parental family also. With the changing times, marriage relationships are being redefined. Young couples want independence and don't like any kind of interference. But many parental families are still living in the past times and have difficulty adapting to the new reality (Iqbal, n.d.). They expect from their daughter-in-law to spend their life by their way. They interfere while they talk, walk, cook or do any household deed etc. The survey highlighted that not only the interference by in-laws family but by wives' parental family also. They were found to do phone talks with their daughters unnecessarily and inquired regarding the each activity of their house and even negatively influenced to their daughter against inlaws. So, these issues really affected their marriage badly and forced the spouses to file divorce petition.

3. Incompatibility Issues: Incompatibility means that the couple has personality conflicts. Incompatibility in marriage makes the relationship aggressive and hostile (Surendran, 2016). It wrecks the mental peace and affects day-to-day marital relationship. Marital incompatibility may be existed in the form of clash of views with husband \& in-laws, differences in age, caste and marital status, consumption of alcohol \& drugs, serious disease to either spouse etc. Additionally, differences were 
found also in the form of living status, cultural background, educational and occupational differences and differences in appearances. When the spouses are not able to cope up with the differences with each other then serious marital discords are generated among them that push their relationship towards failure.

It is true that no two persons can be just similar to each other. But before marriage, it must be fully sure that both the spouses are able to each other. At least, they should not be different in the form of educational qualification, cultural background, living status, economic condition etc. So, compatibility is the real strength of married life. It binds the couple's relationship with love and mutual respect.

4. Economical Reasons: Money really takes a special place to live a peaceful satisfactory marital life. Money problems are one of the most significant reasons that lead to marital breakdowns. Differences in money management issues between spouses can ruin marriage. Unemployment, seasonal work, less income etc. become the cause of serious conflicts among spouses. Most often, male spouses backtrack from their responsibilities of marriage. They are not able to fulfill even the necessary needs of female spouses. It further leads women towards extra-marital affairs, harassments and mental stresses etc.

Economic crisis is becoming Indian marriages stressful at every income level. The apprehension connected with unpaid bills, credit card debt and possible job or home loss seems to bring out the worst in people. Communication breaks down. Differences in money habits begin to blame each other erodes affection (Pedersen, 2018).

\section{Drug Consumption: The cost of drug} consumption is more than financial problems. In marital relationship, one partner abuses drugs or alcohol are usually far less happy than other couples with marital problems. An addict person losses personal integrity, relationships with friends and family, jobs, money and anything else. They may have in an attempt to acquire more drugs. A relationship with partner becomes volatile, nonexistent or often abusive especially if the sober spouse tries to get in the way of the drug or alcohol consumption. Female spouses often feel bad because the issue of drug consumption is concealed (Narconon, n.d.).
The survey highlighted that female spouses were tortured mentally, harmed physically and stressed financially. Husbands didn't do any work. In fact they were dependant on their wives and demand for money to get alcohol or drugs. In few cases, drunkard spouses were found to sell household things and even their children cloths also. It was also reported in the field that husbands' behavior was very aggressive and behaved like insane after consuming drugs. They spoke meaninglessly and used abusive language. Consequently, not only female spouses but their children and other family members had to become the victim of physical and mental abuse.

6. Internet/Mobile Phone Addiction: Technology has provided thousands of advantages to our society. It facilitates us to be more efficient and capable of thousands of tasks that were simply not possible a few years ago. But the new technology is contributing to a rise in the divorce rate in recent times. Spouses have become addicted to their cell phones, lap tops, desktops and their tablets. They use it unnecessarily while eating, working or even travelling. It consequences the avoidance of spouse, communication gap, creates emotional distance and suspicion that harms trust which is the foundation of a healthy marriage.

7. Mental Torture: Mental Torture is one of the forms of physical and sexual abuse. It is one of the most devastating forms of abuse in marriage. Mental abuse is occurred when the spouse is in a position of dominance. This domination may be in the form of financial, social and physical. Life with an abuser is characterized by constant criticism over matters of small consequence, false accusations, threats and malicious humor. According to psychologist, Steven Sosny, this behavior is designed to make you feel unworthy, ashamed, fearful and mentally unstable (Carnes, 2017).

During survey, it was found that women were psychologically abused by their husbands and in-laws. They were physically harmed, badly injured, mentally tortured and sexually harassed. In spite of great social changes, law improvements and rising issues of women empowerment, women are still embarrassed and harassed whether at parental home, in-laws home or at working place. The survey further depicted that women were refused to do job, had restrictions on dress-up, going outside at home or even they were not allowed to cook food by their own choice. So, these 
issues really harm women' self-respect, worst effects on their worth and dignity and influenced their relationship with in-laws.

8. Domestic violence \& dowry harassments: In spite of introducing the well-defined 'The Domestic Violence Act, 2005' and recommendations of certain provisions and legislations, domestic violence is still bruises the lives of millions of people every year. One of the study shows that violence occurs at least one in two-thirds of all marriages, and approximately 95 per cent of the victims of domestic violence are women (Angel \& et. al, 2018). Domestic violence is not just a problem in modern marriages. But it is existed since ancient times. The signs of domestic violence are not always obvious and many of the women don't report that they are being abused. Even the woman's own family is not always supportive at such times, because of the shame and guilt that surrounds such issues (Admin, 2015).

Dowry demand is one of the bad evil that becomes the cause of domestic violence. Dowry is a great burden for the bride's family due to the existence of Antidowry laws. Even the bride's self respect is often affected by the value of her dowry. Research depicted the serious dowry and violence cases in which women were badly harassed and threatened. Even they felt insecure from their husbands in the presence of legal and police officers. They were badly injured, exploited, battered and mentally abused. They became the victim of dowry harassments by so called husbands or other family members.

In recent times, domestic violence cases are resolved out of court with the help of NGOs police officers and counselors by including joint counseling/mediation with husband or her family members/in-laws. But there is a more need for supportive and compassionate atmosphere which plays the great role in helping the victims of domestic violence.

9. Suspicion: Trust is the basic foundation of any relationship. It makes the relationship more strong and healthy especially to marital relationship. If the spouses firm believes on each-other then they can face any challenge in their life. Surendran opines in one of the article that suspicion in marriage is the worst possible crisis which pushes their relationship to the brink of failure. Suspicion destroys the marital happiness. During survey, it was found that the suspicious partner doubt on the every activity of spouse, checked social media functioning and became distrustful when the other spouse talked for a long time in the mobile or interacted friendly with the opposite sex.

10. Unfaithfulness in marriage: Adultery is one of the grounds of divorce. A spouse gets relaxation to pay alimony to an adulterous spouse. It is the most critical situation for a spouse when he/she comes to know an adulterous relationship of other spouse. Commitment is the soul of matrimonial relationship. To dishonor the relationship of a marriage, by being involved in an affair outside the marriage would not only be religiously wrong but morally as well (Pandey, 2017).

The data (in Table 1) depicted that more than onefifth (22 per cent) of spouses had extra-marital affair. Additionally, the data is showing the infidelity of both male and female spouses. Adultery is also one of the legal grounds for divorce. An innocent spouse can show any proof of inclination such as public displays of affection, love letters, text messages and email messages proving unfaithful acts of the other spouse. Pre-marital affairs also become the cause of infidelity in marriage. The spouses are found to continue their illicit relationships due to various economic, emotional and sexual reasons etc.

\section{Other causes}

Various other causes were also found out during research such as concealment of facts, criminal activities, serious disease, misunderstanding, unrealistic expectations and communication gap etc. Besides this, the issues of non-acceptance of girl child, fraudulent NRI marriages, unfulfilled sexual desires etc. became the serious causes of increasing divorce petitions in courts.

\section{Summing Up}

Marriage involves a lot of persons, prestige and personal responsibilities. The outcome of marital dispute involves economic crisis, social accountability and effect on family as well as on children. The institution of marriage is getting influenced from the western societies and the minds of the people which cause the breakdown of marriages and generate some problems that affect the entire society.

There may be no better way than to educate the new generation at early age. Though erotic and passionate impulses are inborn in every individual but marriage 
as an institution is a social construct that needs to be propagated with every generation. Parents have to play a major role in educating their children in family ethos of mutual respect and harmony.

\section{References}

1. Admin, Naaree (2015). How to report domestic violence in India: Call these helpline. Retrieved from: https://www.naaree.com/how-to-reportdomestic-violence-in-india-call-these-helpline on June 25, 2018.

2. Angel, Lisa \& et.al (2018). Divorcing from an abusive spouse: what you need to know. Retrieved from https://www.rosen.com/domestic/darticles/divorce -and-domestic-violence/ on June 13, 2018.

3. Carnes, David (2017). What is mental abuse in a marriage? Retrieved from https://www.livestrong.com/article/138056-whatis-mental-abuse-marriage/ on June 28, 2018.

4. Essays UK (2015). Changing trends in Indian marriages. $\quad$ Retrieved from https://www.ukessays.com/essays/culturalstudies/changing-indian-marriages-culturalstudies-essay.php on June 08, 2018.

5. Fitzgibbons, Richard P (2017). The angry spouse/relative healing. Retrieved from www.maritalhealing.com/conflicts/angryspouse.p hp on April 14, 2018.

6. Gopal, Hemant (2014). The changing concept of Hindu marriages in modern India: with special reference to NRI marriages. Retrieved from $<$ shodhganga.inflibnet.ac.in/bitstream/10603/2652 8/17/17_summary.pdf $>$ on May 25, 2018.

7. Iqbal, Khalid (n. d.). Parents' involvement in the life of married couples. Retrieved from www.rahmaa.org/marriage-issues/parents- involvement-in-the-life-of-married-couple/ June 01, 2018.

8. Narconon (n. d.). Drug addiction and divorce. Retrieved from https://www.narcononnewliferetreat.org/statedrug-information/drug-addiction.org/state-druginformation/drug-addiction-and-divorce.html on June 06, 2018.

9. National Pastoral Initiative for Marriage (2018). How materialism harms a marriage. Retrieved from www.foryourmarriage.org/blogs/howmaterialism-harms-a-marriage/ on June 03, 2018.

10. Pandey, Rishabh (2017). What to do if your husband or wife is having an extra marital affair. Retrieved from <https://blog.ipleaders.in/extramarital-affair/> on June 06, 2018.

11. Pedersen, Mary Jo (2018). How financial difficulties affect marriage. Retrieved from www.foryourmarriage.org/now-financialdifficulties-affect-marriage/ on June 02, 2018.

12. Surendran, Mathi (2016). Top 5 reasons for incompatibility in marriage- Being too opposite. Retrieved from https://www.breezystorm.com/top5-reasons-incompatibility-in-marriage/ on June $13,2018$.

13. Surendran, Mathi (2016). Suspicion in marriage is a devil which destroys your relationship- Never allow it make an unwanted entry. Retrieved from https://www.breezystorm.com/suspicion-inmarriage/ on June 13, 2018.

14. Washburn, Carolyn \& Christensen, Darlene (2008). Financial harmony: A Key Component of Successful Marriage Relationship. Retrieved from $<$ https://ncsu.edu/ffci/publications/2008/v13-n12008- spring/WashburnChristensen.php $>$ on December 08, 2015. 